\title{
Miejsca piesze w przestrzeni miasta
}

\author{
Waclaw Seruga \\ Katedra Architektury i Urbanistyki, Wydziat Budownictwa i Architektury, Politechnika Świętokrzyska \\ e-mail: waclawseruga@poczta.fm
}

\begin{abstract}
Streszczenie: Niniejszy artykuł został poświęcony zagadnieniom związanym z kształtowaniem miejsc pieszych w przestrzeniach miasta. Autor próbuje określić cechy jakie powinny posiadać miejsca piesze kształtujące miejską przestrzeń na podstawie przeprowadzonej analizy trzech zrealizowanych zespołów architektoniczno-urbanistycznych w miastach Słowenii, w drugiej dekadzie dwudziestego pierwszego wieku. Zaprezentowane przykłady o zróżnicowanym programie i funkcji zlokalizowane w różnych uwarunkowaniach potwierdziły tezę, że miejsca piesze stanowią miejsca węzłowe w mieście. Atrakcyjnie kształtowane miejsca piesze harmonijnie powiązane $\mathrm{z}$ otaczającą architekturą oraz kontekstem przestrzennym mają wpływ na integrację przestrzeni w mieście. Miejsca piesze jako miejsca węzłowe w mieście odgrywają w przestrzeniach miast istotną rolę bowiem stanowią wielofunkcyjne płaszczyzny skupiające podstawowy ruch pieszy zapewniając wszelkie kontakty międzyludzkie intelektualne oraz zawodowe, towarzyskie, edukacyjne etc. bardzo charakterystyczne dla przestrzeni publicznych. Mają też wpływ na scalanie zintegrowanych przestrzeni w mieście.
\end{abstract}

Słowa kluczowe: miejsca piesze, przestrzeń miasta.

\section{Wprowadzenie}

Współczesna przestrzeń miejska europejskich miast jest znacznie zróżnicowana pod względem lokalizacji, klimatu, wielkości, a także rozwiązań funkcjonalno-przestrzennych oraz programowych zespołów architektoniczno-urbanistycznych, kompozycji przestrzennej, a także związków ze środowiskiem przyrodniczym oraz zrównoważonym środowiskiem mieszkaniowym. Równocześnie posiada wspólne charakterystyczne cechy historyczne związane ze spuścizną i dziedzictwem kulturowym oraz europejskimi korzeniami i wartościami. Tradycyjna struktura miast europejskich oparta o siatkę ulic i kwartałów została zaakceptowana przez społeczeństwa, a jej zasady kształtowania zostały przyjęte we współczesnych rozwiązaniach przestrzeni miejskich.

Do wielu miejsc węzłowych w mieście należy przede wszystkim zaliczyć miejsca piesze, które stanowiły, stanowią i będą nadal stanowić rolę miejsc skupiających wszelki ruch pieszy o dużej aktywności społecznej związanej z działalnością z zakresu kultury, usług, rozrywki, rekreacji, administracji etc. W skali miasta miejsca piesze pełnią rolę zworników układów komunikacyjnych, funkcjonalno-przestrzennych i kompozycyjnych w strefach śródmiejskich oraz miejskich. Strefy śródmiejskie oraz centra współczesnych europejskich o różnej wielkości miast tworzą w ramach działań związanych z przekształceniami o różnorodnym charakterze; modernizacyjnym, rehabilitacyjnym, rewitalizacyjnym etc. miejsca węzłowe, wśród których dominującą rolę pełnią atrakcyjnie kształtowane miejskie piesze przestrzenie publiczne.

Miejsca piesze w strukturach miast historycznych, stanowią współczesną kontynuację w kształtowaniu przestrzeni miejskich; agory, forum, placu, rynku, ulicy pieszej etc. Współcześnie kreowane są w oparciu o dostępność mierzoną parametrami dojścia pieszego oraz o kontekst funkcjonalno-przestrzenny w zależności od lokalizacji w mieście. Niniejszy 
artykuł dotyczy kształtowania miejsc pieszych w strukturach miejskich poza strefami śródmiejskimi w środowisku mieszkaniowym.

W związku z powyższym warto postawić pytanie - jakie cechy powinny posiadać miejsca piesze kształtujące miejską przestrzeń. W celu zilustrowania omawianych problemów posłużyłem się trzema przykładami zrealizowanych zespołów architektoniczno-urbanistycznych w miastach Słowenii w drugiej dekadzie dwudziestego pierwszego wieku. Zostały one poddane analizie pod kątem wpływu elementów przyrodniczych, kontekstu przestrzennego i kulturowego, lokalizacji, kompozycji przestrzennej, formy architektonicznej, percepcji i innych na atrakcyjność miejsc pieszych kształtujących przestrzeń miejską.

\section{Przykład 1. Promenada w Velenje - $2015^{1}$ Słowenia (Fot. 1-9)}

Promenada jest jedną z centralnych osi centrum Velenje, nowego modernistycznego miasta powstałego w latach 1950-1959 w Słowenii, zaprojektowanego zgodnie z ideą miasta ogrodu. Renowacja promenady stanowi pierwszy etap rewitalizacji centrum miasta, która przebiega pod hasłem „Więcej zieleni i więcej funkcji”. Celem rewitalizacji jest wprowadzenie brakujących funkcji do centrum oraz odzyskanie oryginalnego charakteru miasta w parku. W wyniku transformacji promenada przekształciła się w główną oś kompozycyjną miasta, stanowiąc bardzo atrakcyjną pieszą przestrzeń publiczną o dużej aktywności, która skupia najważniejsze funkcje miasta.

Promenada piesza skupia dwie podstawowe funkcje:

- komunikacyjną, która zapewnia dostępność pieszą użytkownikom do kompleksu szkół średnich i centrum opieki zdrowotnej oraz do funkcji centro twórczych miasta.

- rekreacyjno-spacerową, która zapewnia różne formy wypoczynku dla wszystkich mieszkańców.

Początek promenady stanowi dwupoziomowy parking z funkcją handlową o bardzo oryginalnej architekturze nawiązującej do parkowego otoczenia. Koniec promenady stanowi centrum miasta. Część środkowa promenady, a zarazem punkt kulminacyjny założenia stanowi nowy amfiteatr usytuowany po obu stromych brzegach rzeki Paka, który przecina promenada. Amfiteatralnie schodzące do koryta rzeki szerokie betonowe schody mają przywrócić miastu rzekę, która dotychczas przepływała w bardzo stromym korycie niedostępnym dla społeczności miasta. Atrakcyjny oraz oryginalnie kształtowany amfiteatr nad rzeką z nowym mostem staje się głównym akcentem kompozycyjnego założenia oraz centrum aktywności przestrzeni publicznej w mieście.

Promenada jako miejsce piesze została kreatywnie ukształtowana poprzez wprowadzenie geometrycznie i dynamicznie kształtowanych betonowych płyt wyodrębniając w małej architekturze posadzki przestrzenie do siedzenia. Pasmowe założenie placowe przenikając się płynnie z wysoką zielenią po obu stronach wciąga do kompozycji istniejącą architekturę otoczenia.

Powstaje także nowa architektura wkomponowana w oś promenady, nowoczesny budynek parkingu dwupoziomowego $\mathrm{z}$ funkcją handlową powstały $\mathrm{w}$ ramach programu rewitalizacji miasta. Jego falująca elewacja, która została wykonana z perforowanych arkuszy stali, mocowanych na stalowych słupkach nawiązuje do bezpośredniego założenia parkowego (Fot. 3).

\footnotetext{
1 Promenada w Valenje została zaprojektowana w 2014 roku przez architektów Enota a zrealizowana w 2015 roku. Lokalizacja: Trg mladosti 6, 3320 Velenje, Słowenia. Powierzchnia promenady: 17020,00 m kw. Miasto Velenje jest zlokalizowane w północno-wschodniej części Słowenii. Liczy 33800 mieszkańców. Jest piątym co do wielości i jednym z najnowszych miast Słowenii. Wybudowano je bardzo szybko w latach 50-tych XX wieku, gdy rozwijało się górnictwo węgla kamiennego. Velenje to interesujący przykład socjalistycznej urbanistyki jugosłowiańskiej. Miasto jest jasne i przestronne, dzięki wysokim blokom mieszkalnym i placom. „Velenje Tity” jak nazwano je na cześć Josipa Broza-Tity zostało ukończone w 1959 roku [8]. Źródło: http://www.archdaily.com/636611/promenada-enota (odsłona 04.08.2017).
} 
Rewitalizowana promenada poprzez atrakcyjność oraz jakość rozwiązań przestrzennych i architektonicznych, a także poprzez wciągnięcie do kompozycji przestrzennej rzeki $\mathrm{z}$ amfiteatralnym założeniem wodnym wraz z towarzyszącym ciągiem zieleni oraz otaczającej istniejącej modernistycznej architektury z założeniem parkowym stwarza nową jakość zintegrowanej przestrzeni miejskiej. Równocześnie rewitalizowana promenada scalając wyżej wymienione poszczególne elementy funkcjonale otoczenia w jedną całość porządkuje oraz wprowadza ład w przestrzeni miasta. Rzeka wraz z towarzyszącym ciągiem wysokiej zieleni odgrywa ważną rolę czynnika miastotwórczego w zintegrowanej przestrzeni miejskiej. Stanowiąc ważne miejsce została wyeksponowana w rewitalizowanej przestrzeni.

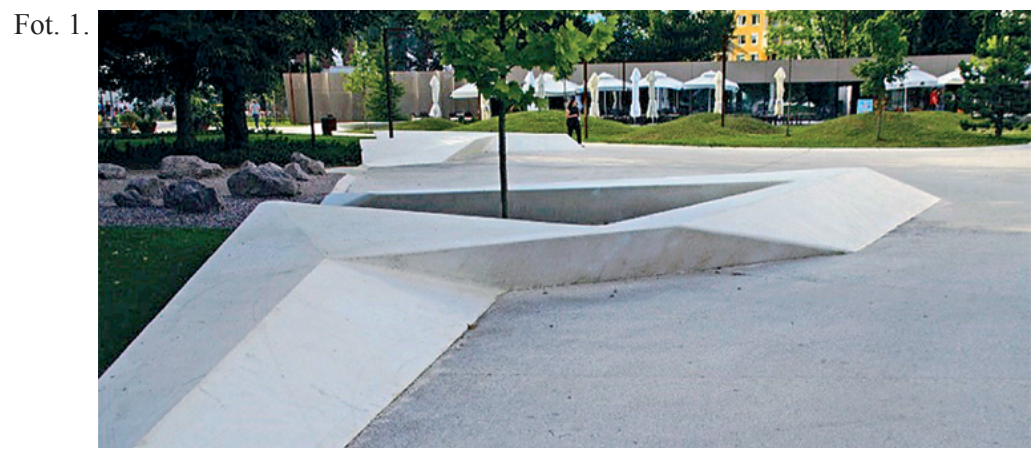

Fot. 2 .

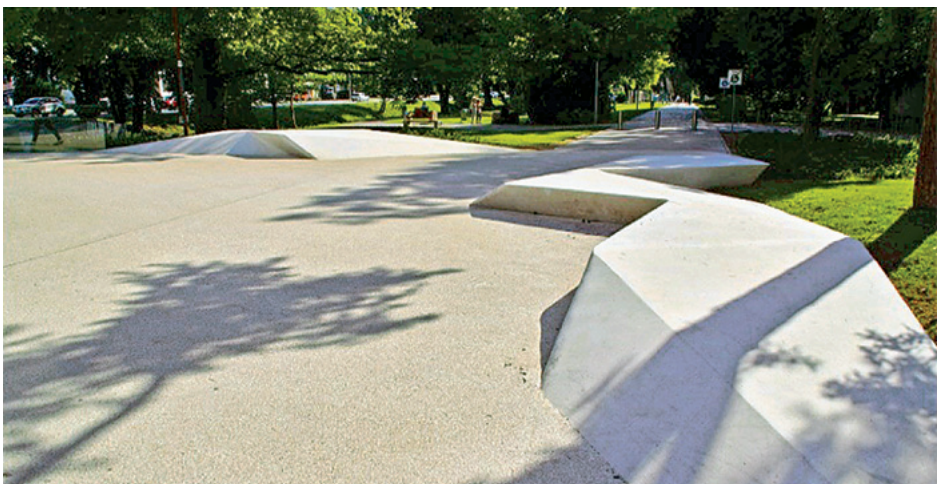

Fot. 1.-2. Promenada w Velenje, Słowenia. Kreatywnie ukształtowana posadzka z betonowych płyt pieszej promenady. Fot. Wacław Seruga 2017

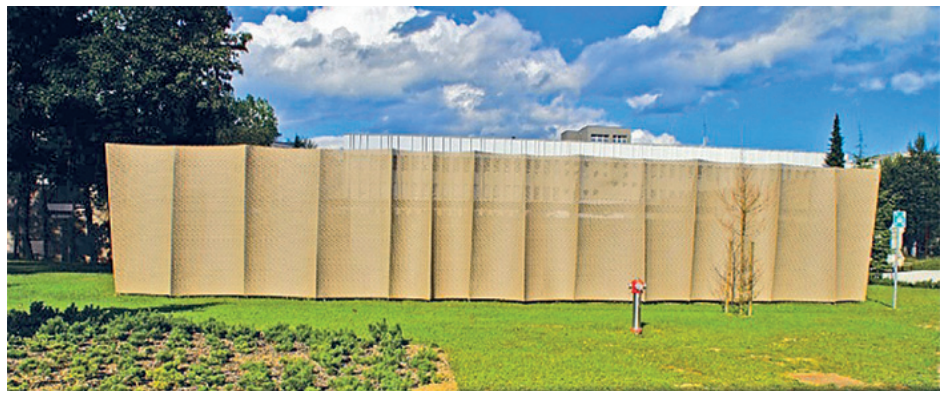

Fot. 3. Falująca elewacja z perforowanych arkuszy stali dwupoziomowego parkingu usytuowanego na osi promenady nawiązuje do parkowego otoczenia. Fot. Wacław Seruga 2017 
Fot. 4.

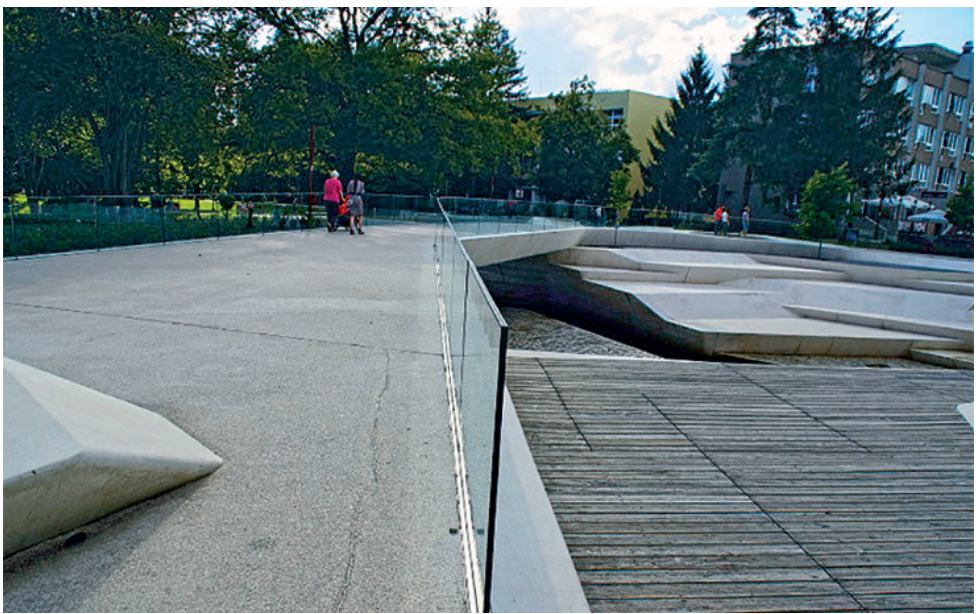

Fot. 5
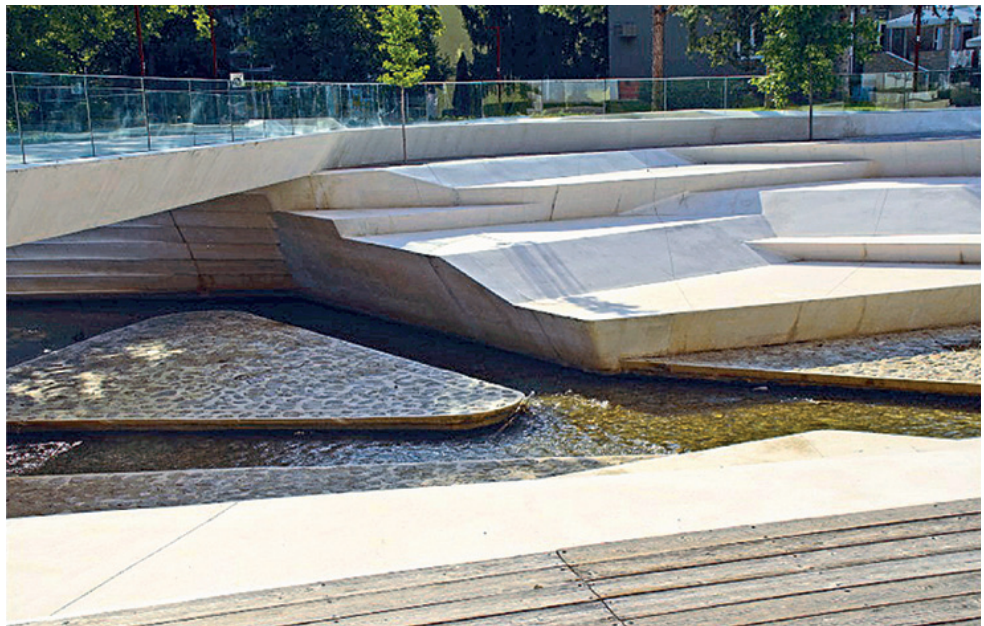

Fot. 6 .

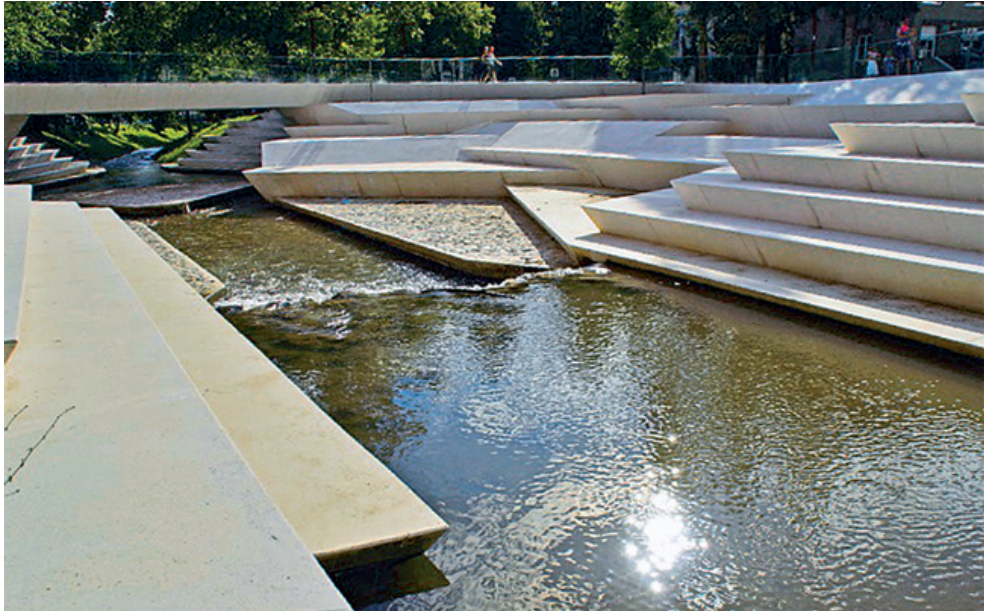

Fot. 4.-6. Amfiteatralne założenie wodne na skrzyżowaniu promenady z rzeką Paka stanowi kulminacyjny punkt kompozycyjny przestrzeni miasta. Fot. Wacław Seruga 2017 
Fot. 7 .

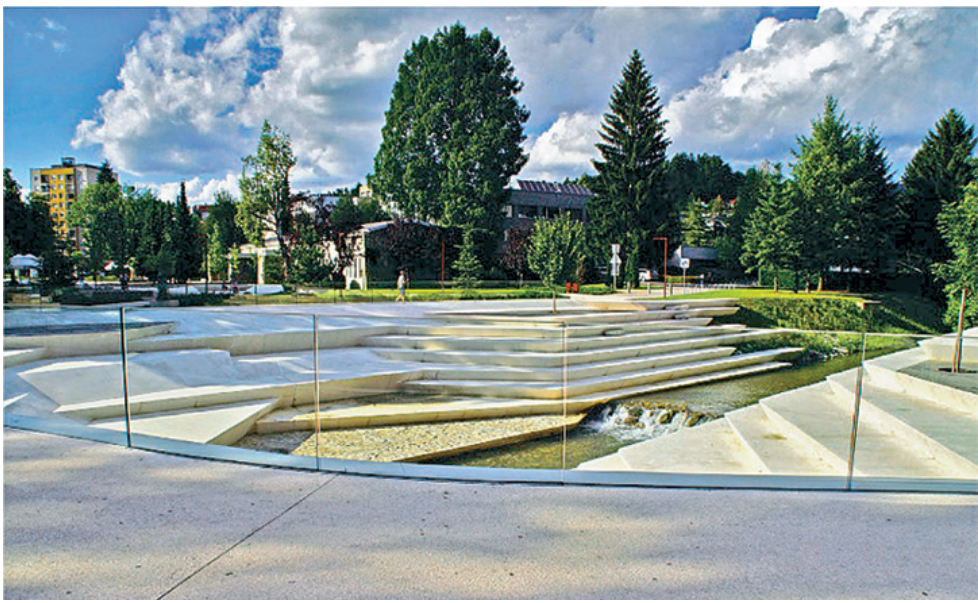

Fot. 8 .

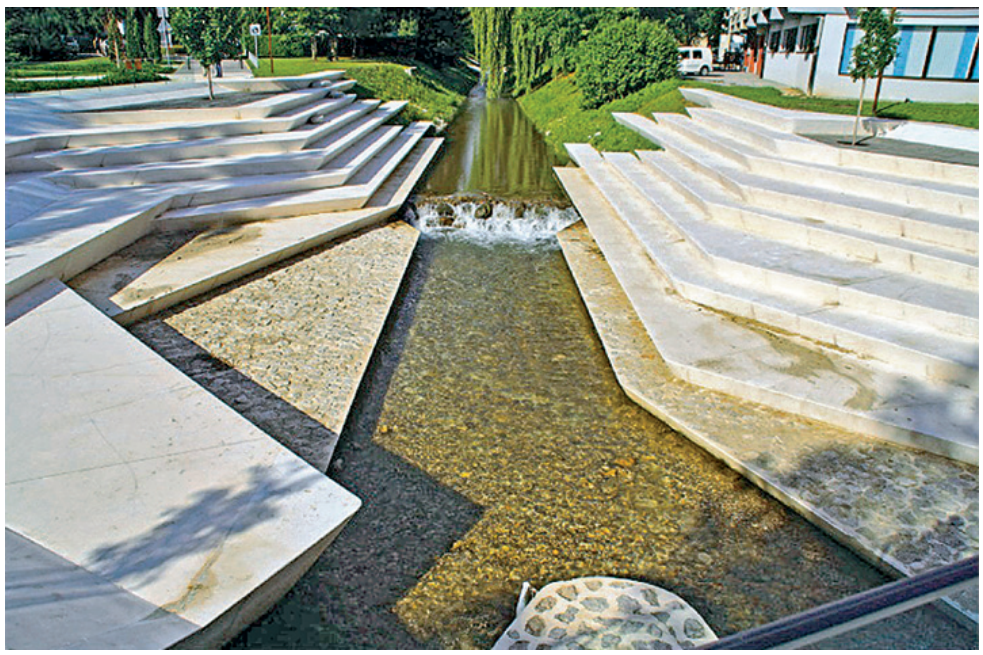

Fot. 9.
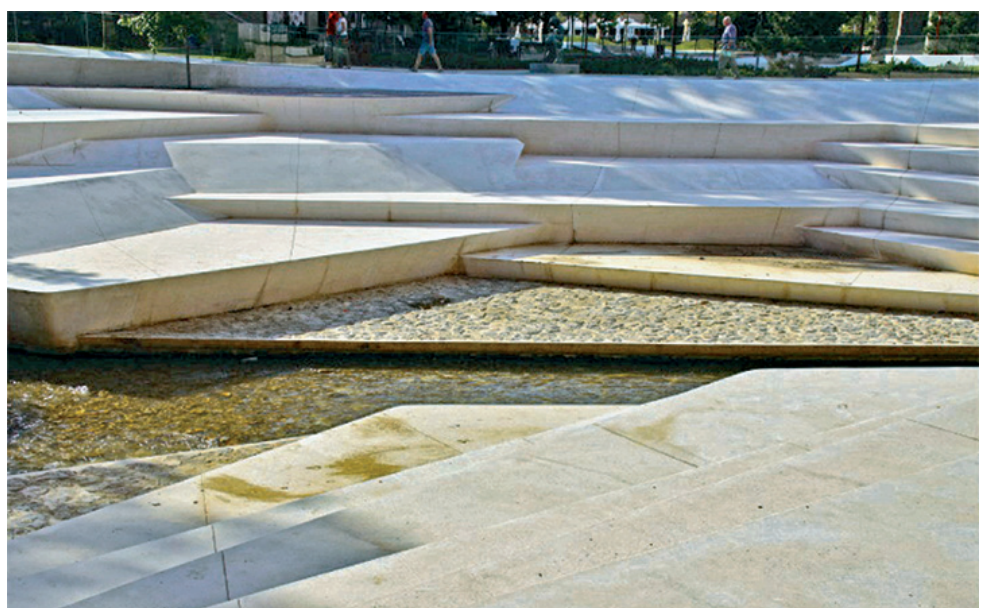

Fot. 7.-9. Atrakcyjny amfiteatr harmonijnie powiązany z rzeką stanowi centrum aktywności przestrzeni publicznej w mieście. Fot. Wacław Seruga 2017 


\section{Przykład 2. Brick Neighbourhood w Lublanie - 2014², Housing Brdo Unit F5 w Lublanie - 2015³, Słowenia (Fot. 10-21)}

W ramach krajowego programu mieszkaniowego Słowenia promuje budownictwo mieszkaniowe. Skuteczna strategia dotycząca budownictwa publicznego jest jednym z podstawowych elementów działań miasta Lublany zorientowanego na jakość i zrównoważony rozwój. W południowej części Lublany realizowany jest obecnie jeden z największych kompleksów osiedli mieszkaniowych w Słowenii, w ramach którego zostały zrealizowane zespoły mieszkaniowe Brick Neighbourhood oraz Housing Brdo Unit F5.

Oba zespoły mieszkaniowe charakteryzuje przyjęta wspólna idea rozwiązania osiedla oparta na linearnie prowadzonym ciągu pieszym przestrzeni publicznej skupiającej funkcje komunikacyjne doprowadzające mieszkańców do mieszkań zlokalizowanych po obu stronach ciągu pieszego, a zarazem tereny rekreacyjne zawierające różnorodne urządzenia do wypoczynku. Znajdują się tu place zabaw dla dzieci, urządzone miejsca do wypoczynku, zieleń oraz oryginalnie kształtowana mała architektura etc. Całość układu harmonijnie wpisuje się w topografię terenu wiążąc przestrzennie i kompozycyjnie zespoły budynków mieszkalnych. Początek ciągu pieszego stanowi „brama wejściowa” w architekturze horyzontalnego budynku handlowego usytuowanego w zespole Housing Brdo Unit F5 na styku ulicy zapewniającej dostępność komunikacyjną do osiedla.

„Jak ustalić jasną, przestrzenną, materialną i społeczną tożsamość” - odpowiedź na to pytanie autorów projektu wpłynęła na jakość rozwiązań funkcjonalno-przestrzennych oraz zintegrowanie przyszłych mieszkańców z miejscem zamieszkania w zespole mieszkaniowym Brick Neighbourhood. Stąd w strukturze zespołu mieszkaniowego pojawiły się duże przestronne i jasne przestrzenie między budynkami oraz wybór cegieł jako materiału pochodzącego z cegielni, która kiedyś stała w miejscu zrealizowanego zespołu. Cegły stanowią okazję do wyrażenia dodatkowej mikrostruktury powierzchni elewacyjnej. Charakterystyczne elewacje wykonane zostały z cegły, która dzięki zastosowaniu odpowiedniego kształtu (ścięty narożnik) pozwala na otrzymanie regularnego wzoru łamiącego monotonię ścian. Powyższe aspekty pozwoliły na budowę unikalnej tożsamości dla przyszłej społeczności. W przestrzeniach publicznych na ścianach oraz drzwiach wypisane są cytaty poetów, każdy z budynków ma swojego „patrona”, z którego poezją można się zapoznać. Wpłynęło to na identyfikację ze swoim otoczeniem, a zarazem wzbogaciło świadomość kulturową mieszkańców. W zespole budynków mieszkalnych liczących 185 mieszkań zastosowano 17 różnych typów mieszkań różniących się wielkością i wewnętrznym układem w celu zaspokojenia różnych potrzeb przyszłych mieszkańców. Balustrady balkonów wykonano z perforowanej blachy.

W rozwiązaniu przestrzennym zespołu mieszkaniowego Housing Brdo Unit F5 położono nacisk na orientację mieszkań i budynków w stosunku do stron świata, ekspozycję widokową na krajobraz oraz na relacje pomiędzy jednostką, a zbiorowością. Jakość życia staje się coraz ważniejsza. Jak definiujemy czas wolny, jaka jest nasza praca i relacje między czasem wolnym i pracą to problemy, które są kluczowe w projektowaniu nowoczesnego zespołu mieszkanio-

2 Zespół mieszkaniowy Brick Neighbourhood został zrealizowany w 2014 roku, a zaprojektowany przez architektów: dekleva gregorič architekti. Lokalizacja: Cesta na Vrhovce 2, 1000 Lublana, Słowenia. Miasto Lublana liczy 250000 mieszkańców. Źródło: http://www.architravel.com/architravel/buildind/bric-neighbourhood/ (odsłona 04.08.2017). Zespoł mieszkaniowy Housing Brdo Unit F5 został zrealizowany w 2015 roku, a zaprojektowany w 2014 roku przez architektów: multiplan architekti. Projekt Team: Aleš Žnidaršič, Katja Žlajpah, Vesna Vraničar, Petra Marinšek. Lokalizacja: Cesta na Brdo 1091000 Lublana, Słowenia. Powierzchnia: 18562,00 mkw. Źródło: http://www.archdaily.com/771224/housing-brdo-unit-f5-multiplan-architekti (odsłona 04.08.2017)

3 Zespoł mieszkaniowy Housing Brdo Unit F5 został zrealizowany w 2015 roku, a zaprojektowany w 2014 roku przez architektów: multiplan architekti. Projekt Team: Aleš Žnidaršič, Katja Žlajpah, Vesna Vraničar, Petra Marinšek. Lokalizacja: Cesta na Brdo 1091000 Lublana, Słowenia. Powierzchnia: 18562,00 mkw. Źródło: http://www.archdaily.com/771224/housing-brdo-unit-f5-multiplan-architekti (odsłona 04.08.2017) 
wego. W wyniku powyższego pojawiły się w architekturze otwarte systemy mieszkań zdolne do zmian funkcjonalnych i adaptacji w celu zaspokojenia potrzeb przyszłych mieszkańców. Zespół mieszkaniowy składa się z 272 mieszkań w trzech typach budynków mieszkalnych o łącznej powierzchni $27500,00 \mathrm{~m}^{2}$ i $16500,00 \mathrm{~m}^{2}$ garażu podziemnego. Cechą charakterystyczną w architekturze budynków są balkony w kształcie przewróconej litery L. Pomiędzy budynkami usytuowano tereny rekreacyjne dostępne dla mieszkańców osiedla.

Linearnie kształtowaną przestrzeń ciągu pieszego cechuje atrakcyjność oraz społeczna aktywność jako miejsca spotkań, kontaktów międzyludzkich, wypoczynku etc. Dominujące w przestrzeni miejsca piesze stanowią najważniejsze miejsca w osiedlu wiążąc elementy środowiska przyrodniczego takie jak zieleń, woda etc. z kompozycją przestrzenną zespołów architektoniczno-urbanistycznych. Linearnie kształtowany ciąg pieszy stanowi miejsce węzłowe w osiedlu mieszkaniowym. Wpływa na identyfikację mieszkańców z miejscem zamieszkania oraz unikalną tożsamość miejsca, a także na integrację miejskiej przestrzeni.

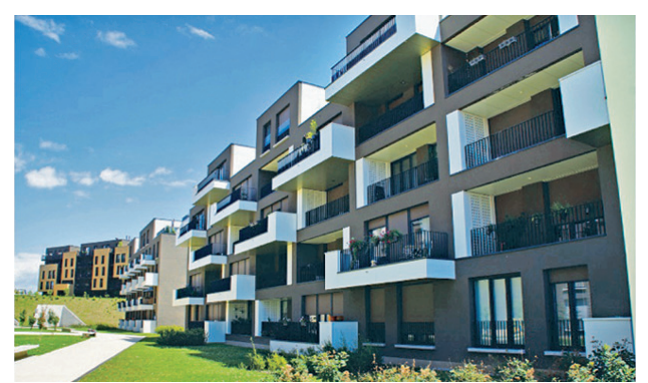

Fot. 10 .

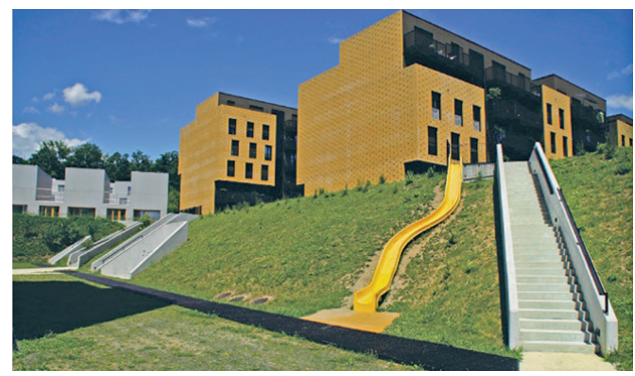

Fot. 12 .

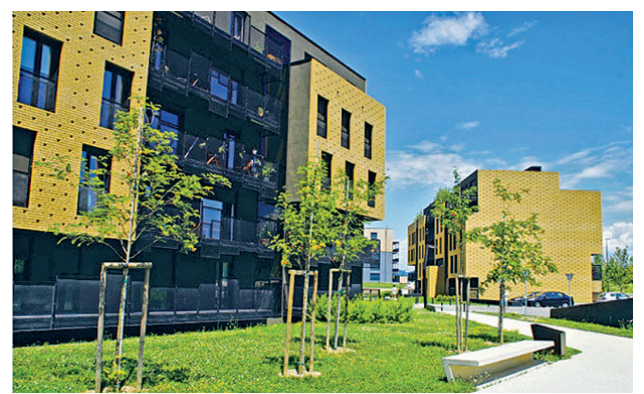

Fot. 14.

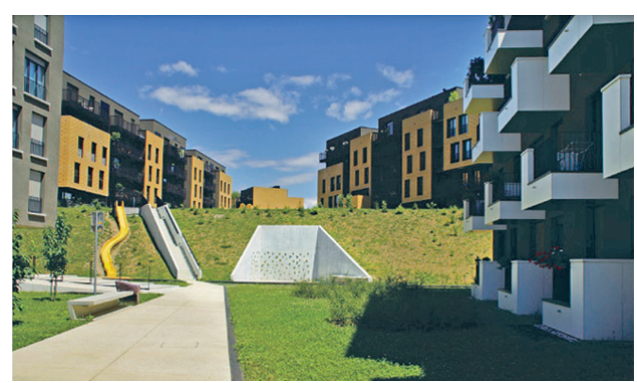

Fot. 11.

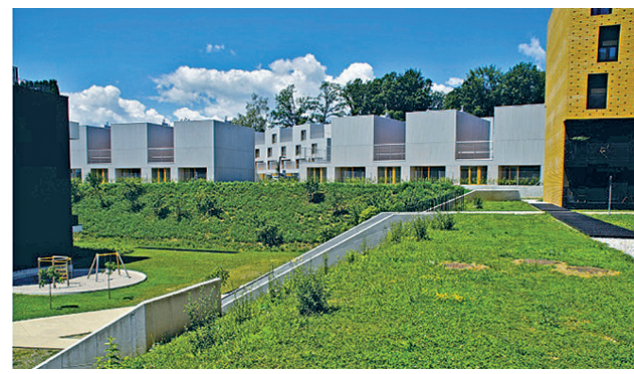

Fot. 13.

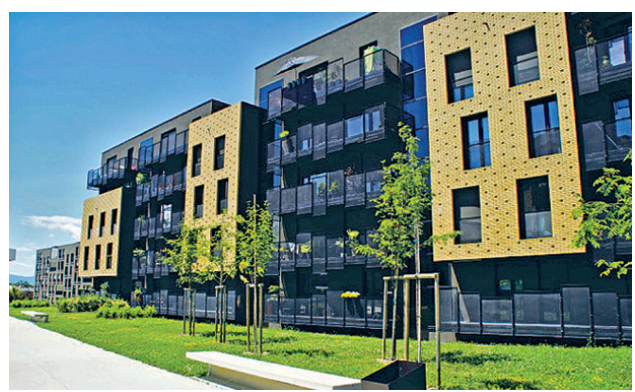

Fot. 15.

Fot. 10.-15. Zespoły mieszkaniowe Brick Neighbourhood oraz Housing Brdo Unit F5 w Lublanie - Słowenia. Linearnie kształtowany ciąg pieszy identyfikuje mieszkańców z miejscem zamieszkania oraz wpływa na unikalną tożsamość miejsca. Fot. Wacław Seruga 2017 
Fot. 16.

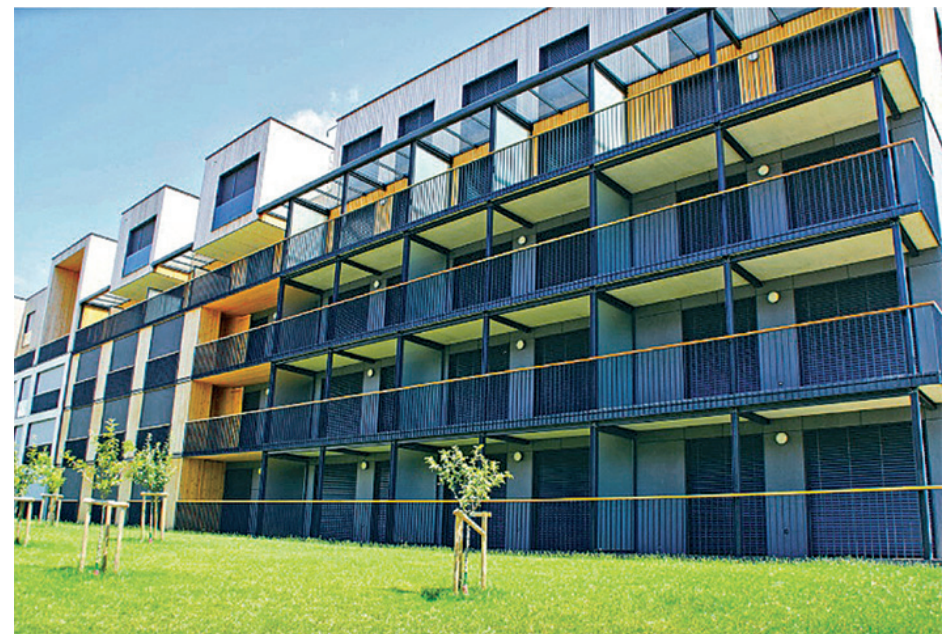

Fot. 17.

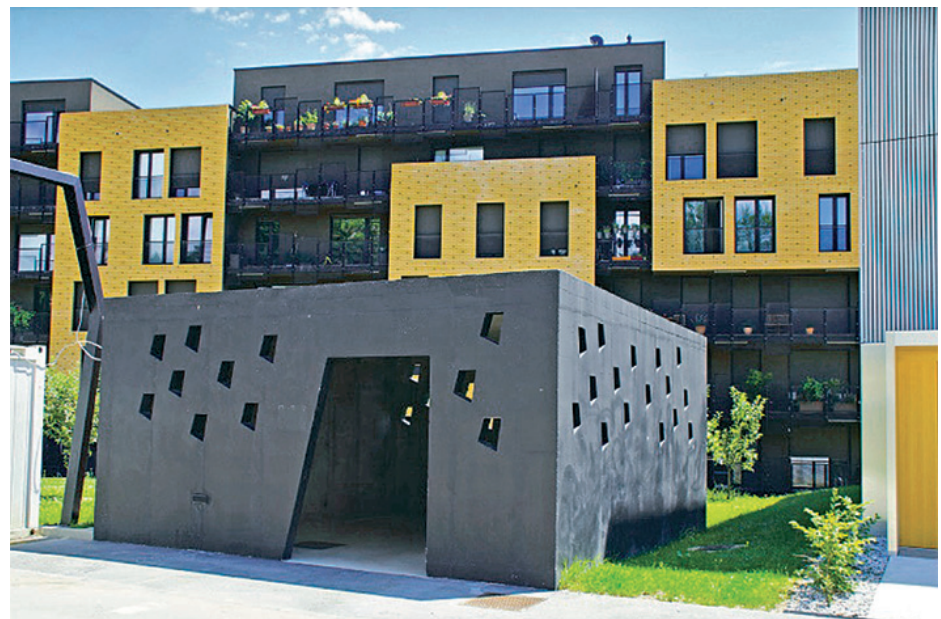

Fot. 18.

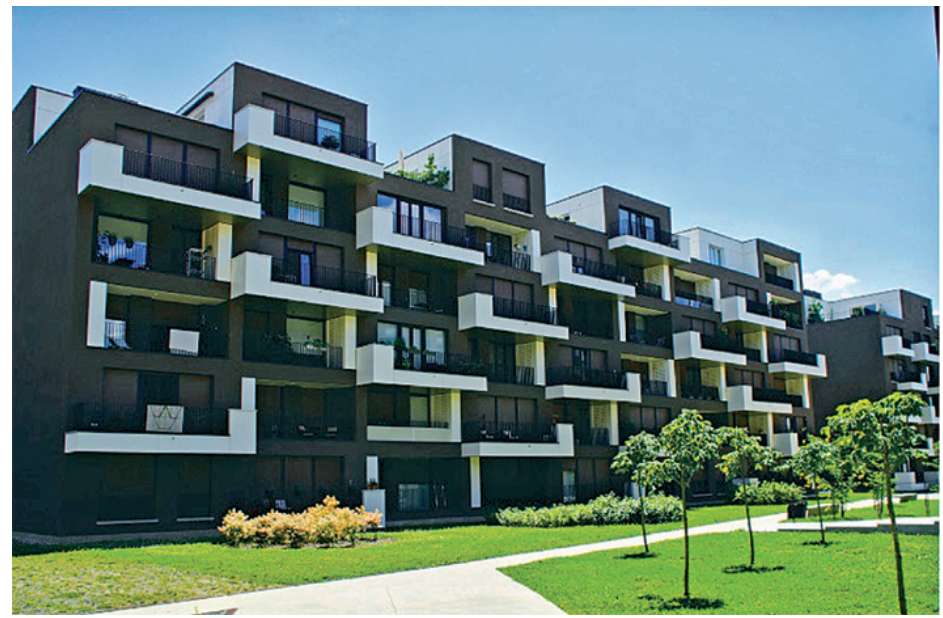

Fot. 16.-18. Architektura mieszkaniowa integrująca miejską przestrzeń. Fot. Wacław Seruga 2017 
Fot. 19.

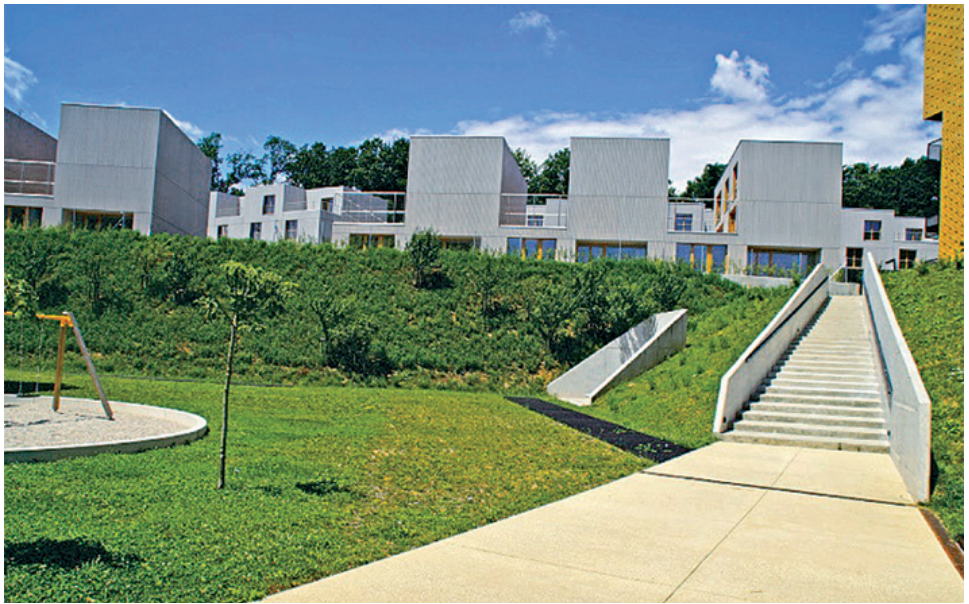

Fot. 20 .

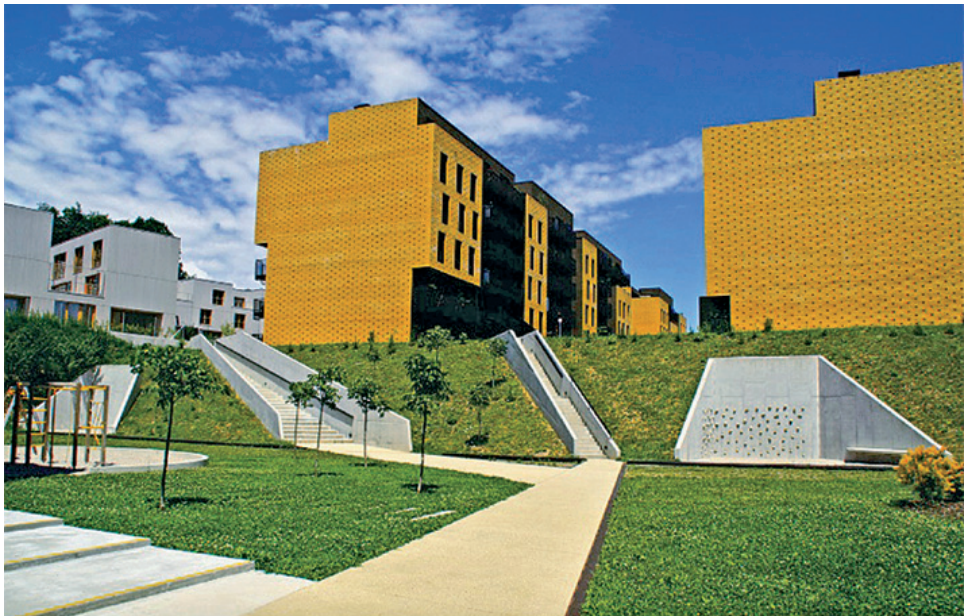

Fot. 21.
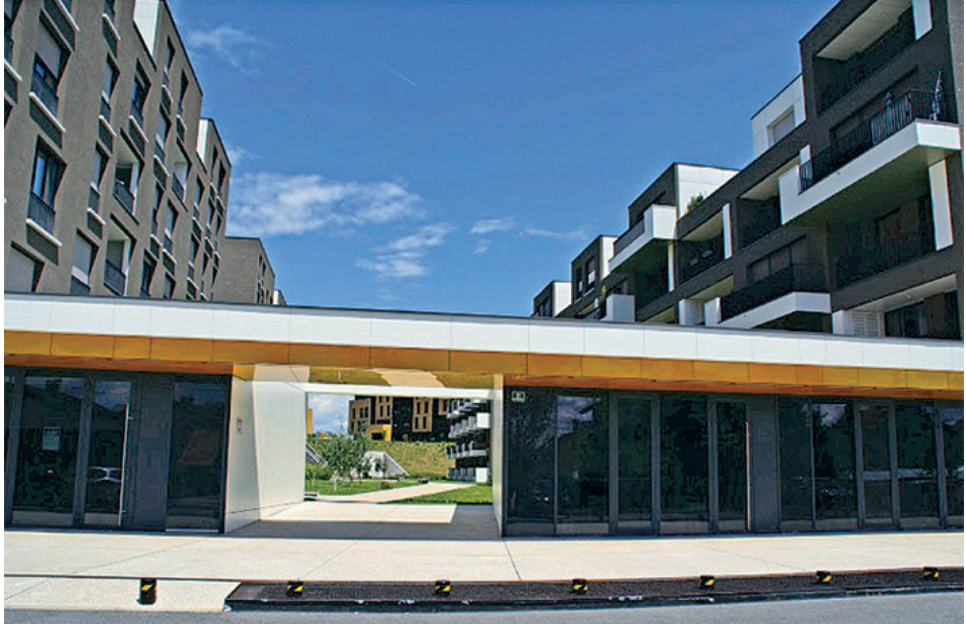

Fot. 19.-21. Miejsca piesze stanowiące miejsca węzłowe w mieście kształtują miejską przestrzeń osiedla mieszkaniowego w Lublanie. Fot. Wacław Seruga 2017 
Fot. 22

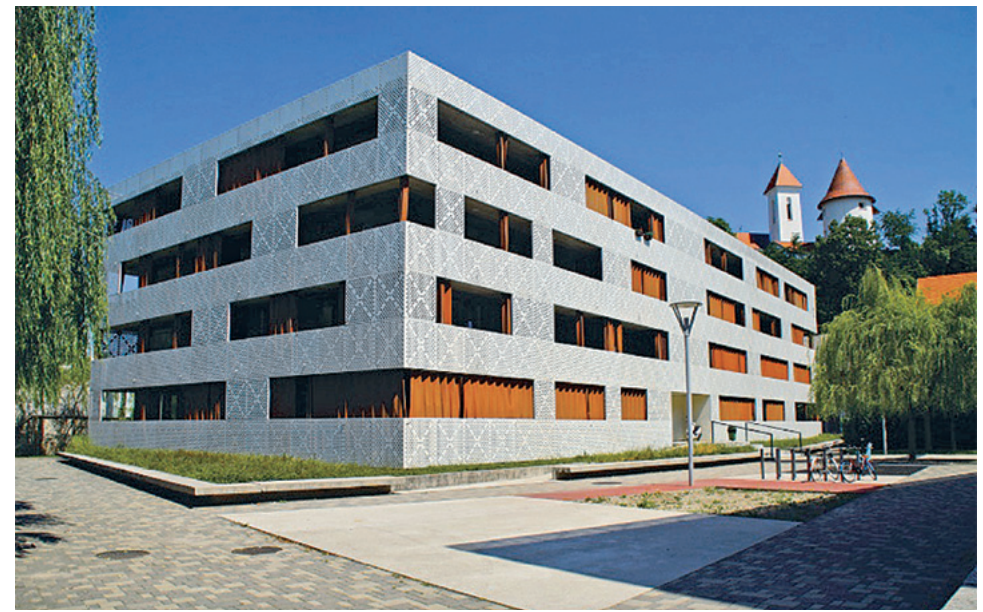

Fot. 23.

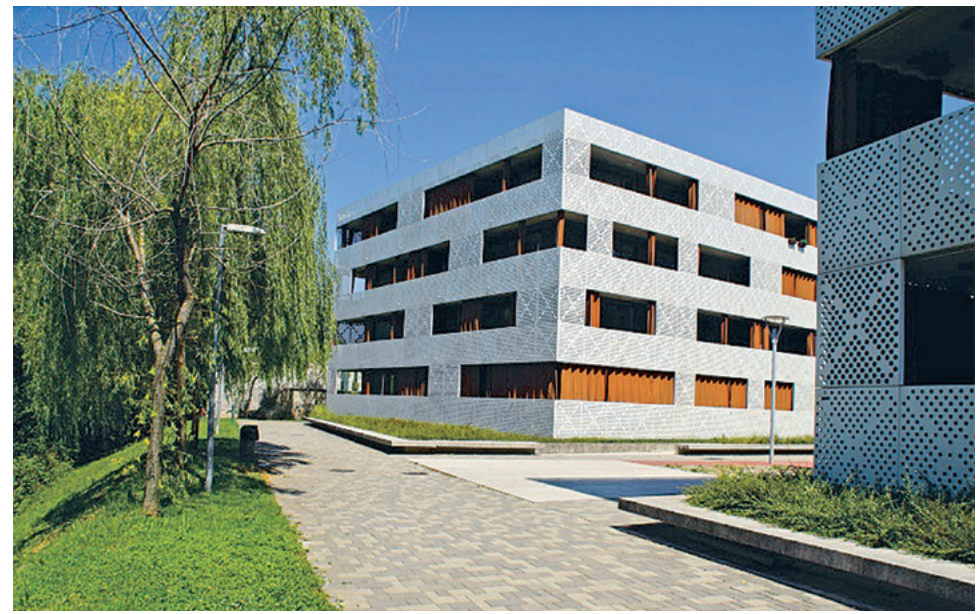

Fot. 24.

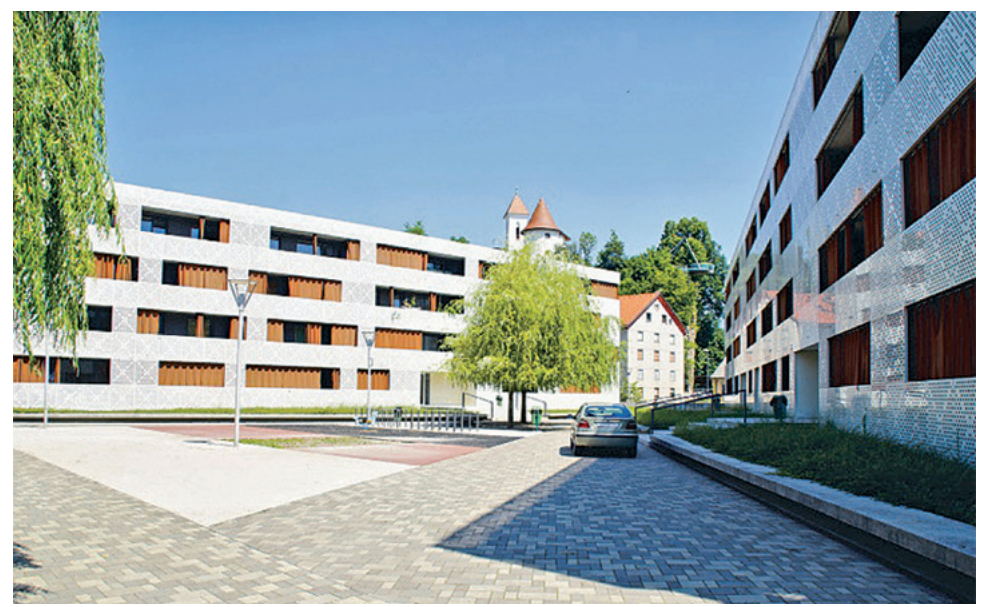

Fot. 22.-24. Housing Sotocje w Kranju-Slowienia. Rekreacyjny ciąg pieszy założenia urbanistycznego integralnie powiązany przestrzennie z rekreacyjnymi wnętrzami mieszkalnymi. Fot. Wacław Seruga 2017 
Fot. 25

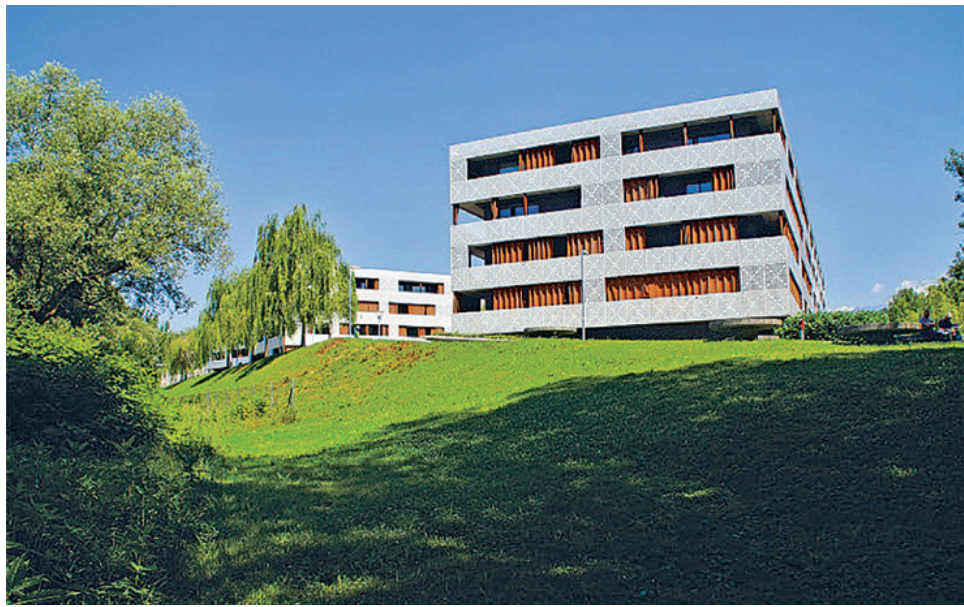

Fot. 26 .

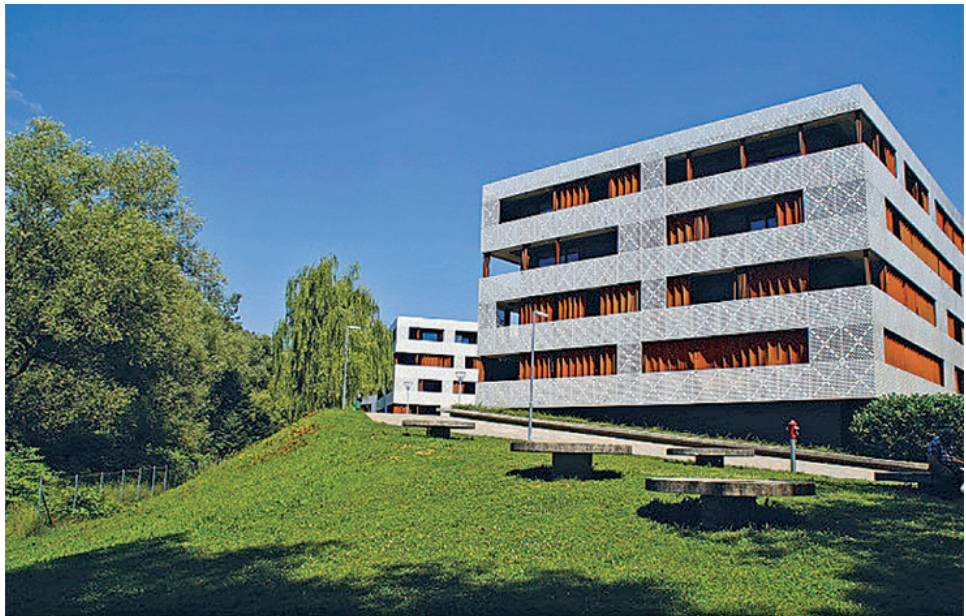

Fot. 27

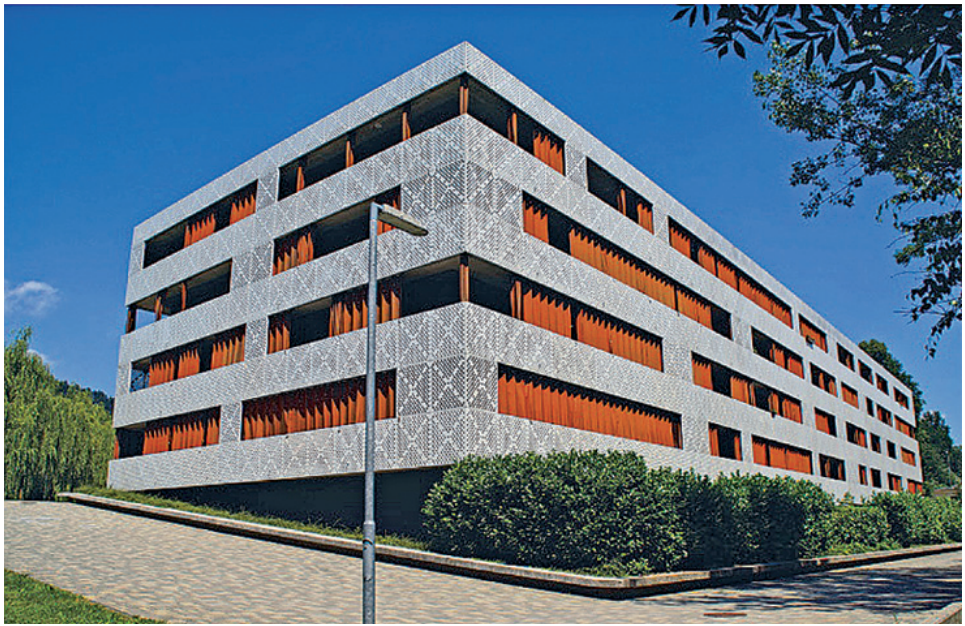

Fot. 25.-27. Architektura budynków mieszkalnych harmonijnie wkomponowana w rekreacyjne otoczenie rzeki Savy. Fot. Wacław Seruga 2017 


\section{Przyklad 3. Housing Sotocje w Kranju - 2010 ${ }^{4}$ Słowenia (Fot. 22-27)}

Zespół mieszkaniowy Sotocje został zlokalizowany u zbiegu rzek Sava i Kokra w Kranju, w dziewiętnastowiecznym obszarze przemysłowym na styku z historycznym centrum oraz terenami rekreacyjnymi o wysokich walorach przyrodniczych. Uprzednio stała tam fabryka kauczuku powodując silne zanieczyszczenie terenu. Obecnie obszar ten jest przekształcany i powstają tam zespoły mieszkaniowe o dużych walorach ekologicznych w zrównoważonym środowisku mieszkaniowym. Zespół mieszkaniowy Sotocje liczący 142 mieszkań został usytuowany w widłach obu rzek na podniesionej naturalnej zielonej platformie zawierającej garaże tuż pod dawnym średniowiecznym miastem położonym na wzgórzu.

Kompozycja przestrzenna zespołu oparta została na osi pieszego rekreacyjnego zielonego ciągu usytuowanego wzdłuż brzegu rzeki Savy powiązanego z zielonymi rekreacyjnymi wnętrzami kształtowanymi przez czterokondygnacyjne budynki mieszkalne. Rekreacyjny, a zarazem integrujący ciąg pieszy jest elementem wiążącym przestrzenie rekreacyjne zespołu architektonicznego z przestrzenią środowiska przyrodniczego rzeki Savy. Architektura budynków mieszkalnych jest niezwykle lapidarna w formie.

W elewacji zastosowano perforowane panele aluminiowe. Wszystkie mieszkania bardzo proste w układzie posiadają balkony otaczające cały budynek od zewnątrz tworząc efekt „głębokiej fasady” pomiędzy dwoma warstwami elewacji: „termicznej” i „wizualnej”. Zespół mieszkaniowy Sotocje zrealizowany w wyniku rewitalizacji zdegradowanych terenów poprzemysłowych scala średniowieczne miasto położone na wzgórzu w rejonie rzeki Savy z istniejącą tkanką miejską podnosząc zarazem jakość i atrakcyjność miejskiej przestrzeni.

\section{Podsumowanie}

Zaprezentowane przykłady zespołów architektoniczno-urbanistycznych potwierdzają tezę, że miejsca piesze stanowią miejsca węzłowe w mieście. Miejsca piesze to swoiste hybrydy pełniące rolę wielofunkcyjnych przestrzeni zmieniających swoje oblicze, charakter i klimat w zależności od potrzeb. Mogą pełnić rolę przestrzeni publicznych o dużej aktywności komunikacyjnej jako miejsca spotkań, różnorodnych imprez, koncertów, kiermaszy, wypoczynku, rozrywki etc. o dominującym programie np. kulturalnym, usługowym, rekreacyjnym etc. Atrakcyjnie kształtowane miejsca piesze harmonijnie powiązane z otaczającą architekturą oraz kontekstem przestrzennym mają wpływ na integrację przestrzeni w mieście.

Miejsca piesze kreują w przestrzeniach miejskich formy małej architektury i rzeźby oraz różnorakie geometryczne kształty jak promenady, place, ciągi i ulice piesze, etc. powiązane z elementami natury: wody, zielni, rzeźby terenu itp. Występują w różnych skalach w miastach o rożnej wielkości tworząc indywidualny układ sieciowy wzajemnych powiązań funkcjonalno-przestrzennych i kompozycyjnych. Zwykle towarzyszą im ciągi zieleni parkowej oraz zbiorniki lub cieki wodne.

Miejsca piesze kształtujące miejskie przestrzenie posiadają miedzy innymi następujące cechy:

\footnotetext{
4 Housing Sotocje został zaprojektowany w 2009 roku, a zrealizowany w 2010 roku w Słowenii w miejscowości Kranj przy ul. Savska cesta przez architektów Bevk Perović architekti. Projekt Team: Matija Bevk, Vasa J. Perović, Davor Poćivašek, Ida Seduśak. Kranj to czwarte pod względem wielkości słoweńskie miasto i ośrodek przemysłowy. Posiada ładną starówkę rozciągającą się na cyplu w miejscu, gdzie kiedyś osiedlili się Celtowie, a później Rzymianie. Miasto zlokalizowane $15 \mathrm{~km}$ od Lublany, obecnie liczy 53000 mieszkańców. Źródło: http://www.archdaily.com/81163/housing-sotocje-bevk-perovic-architekti (odsłona 04.08.2017)
} 
- atrakcyjność kształtowania miejskich przestrzeni,

- harmonia z otaczająca architekturą,

- wysoka jakość rozwiązań elementów małej architektury, posadzki, rzeźby etc.,

- przyjazna percepcja użytkowników tych przestrzeni,

- w rozwiązaniach funkcjonalno-przestrzennych uwzględniają kontekst przestrzenny i kulturowy oraz elementy środowiska przyrodniczego jak woda, zieleń etc.

- posiadają niezwykłe walory kompozycyjne.

Miejsca piesze jako miejsca węzłowe w mieście odgrywają w przestrzeniach miasta istotną rolę, bowiem stanowią wielofunkcyjne płaszczyzny skupiające podstawowy ruch pieszy zapewniając wszelkie kontakty międzyludzkie intelektualne oraz zawodowe, towarzyskie, edukacyjne etc. bardzo charakterystyczne dla przestrzeni publicznych. Mają też wpływ na scalanie zintegrowanych przestrzeni w mieście.

\section{Bibliografia}

[1] Gzell S. Wykłady o współczesnej urbanistyce, Warszawa 2015, Oficyna Wydawnicza Politechniki Warszawskiej.

[2] Kosiński W. Paradygmat miasta 21 wieku, Politechnika Krakowska 2016 r.

[3] Pluta K. Przestrzenie publiczne miast europejskich. Projektowanie urbanistyczne. Warszawa 2014. Oficyna Wydawnicza Politechniki Warszawskiej.

[4] Podhalański B. Integrowanie przestrzeni metropolitalnych, Monografia 443 seria Architektura, Wydawnictwo: Politechnika Krakowska, Kraków 2013 r.

[5] Seruga W. Architektura kontekstu. Monografia - Architektura 1/2014; Wydawnictwo: Politechnika Świętokrzyska, Wydział Budownictwa i Architektury, Kielce 2014r.

[6] Seruga W. Kreacja w przestrzeni miasta. Rozdział [w:] Architektura kontekstu. Monografia - Architektura 1/2014, str. 84-104. Wydawnictwo: Politechnika Świętokrzyska. Wydział Budownictwa i Architektury, Kielce 2014 r.

[7] Seruga W. Rekreacja w małych zespołach mieszkaniowych [w:] Rekreacja w miejscu zamieszkania, Środowisko Mieszkaniowe/Housing Environment nr 16/2016, str. 132-171; Wydawnictwo: Katedra Kształtowania Środowiska Mieszkaniowego, Wydział Architektury, Politechnika Krakowska, Kraków 2016 r.

[8] Słowenia - Przewodnik Wiedzy i Życia, Warszawa 2013.

[9] Wrana J. Rola i znaczenie architektury $w$ procesie scalania struktury przestrzennej miasta na przykładzie Lublina. Monografia. Wydawnictwo: Politechnika Lubelska, Wydział Budownictwa i Architektury. Lublin 2014 r.

\section{Pedestrian areas in the space of a city}

\section{Waclaw Seruga}

Department of Architecture and Town Planning, Faculty of Civil Engineering and Architecture, Kielce University of Technology, e-mail: waclawseruga@poczta.fm

\footnotetext{
Abstract: This article has been devoted to problems associated with the shaping of pedestrian areas within the spaces of a city. The author attempts to determine the characteristics
} 
that pedestrian spaces - which shape urban space - should possess on the basis of an analysis of three built architectural and urban complexes in the cities of Slovenia dated to the second decade of the twenty first century.

The examples that were presented - each having a different programme and form of use, as well as being located in different conditions - confirmed the thesis that pedestrian areas constitute node areas within a city. Attractively shaped pedestrian areas connected with the surrounding architecture and spatial context have an impact on the integration of spaces within a city.

Pedestrian areas - as node areas within a city - play a significant part within the spaces of cities, as they constitute mixed-use planes that focus basic pedestrian traffic, providing all manners of interpersonal contact: intellectual and professional, social, educational, etc., which is very characteristic of public spaces. They also have an impact on the merging of integrated spaces within a city.

Keywords: pedestrian areas, the space of a city. 